\title{
Academic Lives
}

\author{
Jane Dutton, ${ }^{1}$ Linda Groat, ${ }^{1}$ Jane Hassinger, ${ }^{1}$ Lora Lempert, ${ }^{2,4}$ and \\ Carolyn Riehl ${ }^{3}$
}

Fields of Play: Constructing an Academic Life, by Laurel Richardson. New Brunswick, NJ: Rutgers University Press.

In the late spring of 1997, eight women from The University of Michigan came together at the Institute for Research on Women \& Gender to consider how feminist theory and organization theory might inform each other and how we could bring the epistemological perspectives, methodologies, and theoretical insights of feminist theory to bear on our own work, particularly our inquiries into organizations and the experiences of individuals within them. Our academic affiliations are diverse: we come from architecture, business, education, political science, psychology, public policy, social work, sociology, and women's studies. Our research interests are eclectic as well. In our weekly meetings, we recommend books and articles to one another and have selected several to study together. We also read and discuss each other's work and, inevitably, talk about our own organizational lives and how they intertwine with our personal lives. We have rather quickly become a cohesive group, jealous of our time together and increasingly mindful of how much we appreciate, sometimes even depend upon, the intellectual stimulation and personal support that we draw from each other. Over the summer, one of our common readings was Fields of Play: Constructing an Academic Life, by Laurel Richardson. So, in the fall, when Lora Lempert was asked by the editors of this journal to write a review of the book, it seemed only natural to propose enlisting these friends and colleagues in producing a review. The editors agreed; our study group considered alternative approaches to the task; and we finally decided to

\footnotetext{
${ }^{1}$ The University of Michigan, Ann Arbor.

${ }^{2}$ The University of Michigan, Dearborn.

${ }^{3}$ Eastern Michigan University.

${ }^{4}$ Direct correspondence to Lora Lempert, Department of Behavioral Sciences, The University of Michigan, Dearborn, Dearborn, MI 48128; e-mail: llempert@umich.edu.
} 
review the book in a conversational format, since that is how we had engaged with the book several months earlier.

After a few preparatory discussions, five of us met in the back room of a local restaurant (three members could not be present due to illness or family exigencies). With two tape recorders on the table and an accommodating wait staff to provide us with refreshments, we spent several hours sharing our reflections on Richardson's book. The conversation was transcribed, producing over 40 pages of text. Although this review flows from that bona fide conversation, we have edited it collectively, of course, to make it more easily readable.

The group members who participated in the conversation were Jane Dutton (business and psychology), Linda Groat (architecture), Jane Hassinger (social work, psychology, and women's studies), Lora Lempert (sociology and women's studies), and Carolyn Riehl (education and sociology). Present in spirit, but not body, were Martha Feldman (political science and public policy), Beth Reed (social work and women's studies), and Raven Wallace (education).

\section{THE REVIEW}

Lempert: I found this book by turns both terrifying and exhilarating. Terrifying in the lessons of caution about the academy-in Richardson's unmasking of the patina of the free exchange of ideas and the consequent sanctions that accrue to those who deviate from the dominant paradigmsand exhilarating in her flights of intellectual freedom and in what she has to say about power-her own and our power as ethnographers.

Groat: I very much identify with her autobiographical accounts. Because I came to a place with tenure having been appointed associate dean, I thought that I had enough standing, so to speak, to be able to try and help others and to enable the voices of women in my field, which is architecture. And the more I got into it, the more I felt the repercussions to me. And yet in the same way as she's experienced, it doesn't make you stop. It just makes you feel all the more determined that you should do it.

Dutton: I had a different reaction, but similar in spirit. I loved her outrageousness and her daring to do what she calls writing these texts of illegitimacy. The "good girl" in me finds it such a joy to have her open up these spaces by both taking on and playing with the hard surfaces of the academy. I'm in the field of organization studies and in my world Laurel Richardson's acts would be truly outrageous. 
Riehl: I found her explorations in illegitimacy intriguing too, and yet it raised real questions for me about who has the power to define what intellectual work is legitimate and what is illegitimate. Certainly, the researcher herself has a role in that process. But the academy also has a voice, and potential audiences do as well. Legitimacy is, it seems to me, more of a collective determination than Richardson seems to acknowledge.

And yet $I$ found her efforts to break free from conventional expectations to be so inventive and so brave. Her work is fresh, if sometimes rather self-absorbed. None of the many abstract, almost clinical descriptions of the academy's constraints on inquiry are as painfully real as Richardson's personal account of how she experienced such constraints and what it was like to push back.

Hassinger: I'm a psychotherapist and a teacher. I was at first stunned and shaken by how personal this book is-perhaps an unexpected reaction from a psychotherapist. I imagine my response reflects the role contradictions I juggle as I move between my two professional domains. One is highly personal, reflective, and self-revealing. The other is more guarded, organized, and concerned with controlling emotion and avoiding an overly personalized approach to subject matter in the classroom.

As a feminist therapist, I'm much interested in careful exploration of a woman's personal history and helping to reveal how that history is embedded in patriarchal, social contexts that are gendered and racialized. I'm concerned with looking into marginalized and devalued sources of insight and knowledge and with helping a person to free her potentials, her feelings, her voice. As a feminist teacher, I also value this undertaking. But in the university, in spite of the now prominent impact of feminist theory and of my very clear commitments to a feminist pedagogy, I still feel traces of suspiciousness and fear about the emergence of the personal, the idiosyncratic, the emotional in my classrooms. The threat of being found out and discredited still haunts and underlies a cautiousness I can never quite shake. Richardson shakes it, throws it off and up and throttles it. And so, at first, her book heightens my awareness of my own caution and feelings of painful inauthenticity. Ouch!

Lempert: Yes. What strikes me is Richardson's absolute ability to know what her authentic self is and to be it. I think that's a confusion for a lot of women in general and a real problem for academics because we get socialized into a discipline that tells us how to be. In order to be a successful "sociologist" or "architect" or "social worker," you have to be it in 
a particular way. Trying to hold your own voice becomes very difficult, but she does it.

Hassinger: She does it! She doesn't lie. I think she is able to do it because she has been able to hold on to her sense of entitlement to a point of view and her rage at being pressured to do otherwise. She talks about being mad, fighting mad and how this offers her a critical edge.

I'm thinking now about her story about being a child at Camp Olivet and refusing to read Christian scripture that violated her hold on her halfJewish identity, in spite of the risk of severe sanctions from her Jewish mother. Interestingly, she was later supported by her father for her act of resistance-authorized in her anger and in her voice early on by her father, something so essential but so elusive for most of us!

Dutton: I just want to affirm that there were many places where she would characterize the academy in ways that resonated with how I feel. I just feel sometimes ill-equipped to speak. She could speak for me. For example, when she's characterizing the way that sociologists write. And she says, quote: "Nearly every time sociologists broke out into prose they tried to suppress (their own) life: passive voice, absent narrator, long, inelegant repetitive authorial statements and quotations; 'cleaned up' quotations, each sounding like the author..." I could go on. I mean, I'm breathless! I have felt that way but I can't say it! So for me, some of my personal connection to the book comes from her characterization of how she sees the field in relationship to her and what she's trying to accomplish.

Hassinger: I am a part-time academic who has lots of trouble getting any writing done, partly for reasons of exhaustion and partly out of a struggle to find a comfortable academic prose style. Early in the book, Richardson discusses the so-called rational/irrational split in the academy and its impact on scholarship. She points out that in common talk rational means sane. The rational person is emotionally integrated, tolerant of ambiguity, openminded, and connected to others through a capacity for empathic communication and intimate sharing. Stands to reason that the writing of a rational person might suggest these qualities. It was exhilarating to find my own private feelings about academic writing reframed and reauthorized in her critique of academic discourses which she experiences as insanity-producing.

Groat: I found that very compelling, but at the same time I thought about how some of those dynamics play out in my field, which is architecture. I see this grand shift, which Richardson articulates, as somewhat comparable 
to the rather pendulum-like swings that occurred in architecture throughout the 20 th century.

To be specific, the rational, empirical, "scientific" orientation has been represented by architects who would argue that the most appropriate role for the architect is as a technician, someone who is responsive to the broad societal and technical forces of the times. In other words, someone who can correctly analyze these forces and provide a solution to the environmental problem at hand.

The problem, of course, is that the architect-as-technician model obscures the significance of the architect's agency. So the tendency has been for the pendulum to swing radically to the other side, whereby the architect is conceived as the artist. This seems to me to be substantially analogous to Richardson's attempt to abandon the objectification and scientism inherent in sociology and to shift boldly to what is essentially an artistic stance.

But the artist model is equally problematic; it can easily lead to a mode in which the artist is propelled to creative self-expression, often disengaged from the larger cultural discourse. In my own writing, I have argued for a "culturalist" perspective in which the architect-or in this context the researcher -takes a more powerful role as a "cultivator" who is both engaged with the larger scope of community life, yet also conveys the depth of a personal and individual perspective.

Lempert: How do we get to the center if we don't have somebody pushing the envelope? If you only push to the center, the center becomes the envelope. I think that you have to have the valiant souls who push it and take the heat to create the space behind them. Richardson, Denzin, Clough are some of the people in sociology who really push it. They are the folks creating the intellectual and representational space for the rest of us to move around more freely.

Riehl: I sometimes introduce my students to innovative theorists by describing them as swashbucklers in the jungle, cutting a rough new path through unfamiliar terrain, leaving their followers to make the path more neat and orderly. I guess swashbucklers don't really belong in the jungle, do they, but instead on the high seas? Perhaps that mixed metaphor only enhances the sense of a thinker embarking on a journey where she doesn't yet belong. In any case, while I read Richardson as attempting something new in this book, it did not strike me as cutting a rough swath. She is pushing barriers aside the way and explorer might bend tree branches out of the way, but her writing exudes an awareness that suggests she has al- 
ready been on the path many times before taking the reader along with her. I found this reassuring.

Hassinger: And that's part of the space you're taking about. She's trying to make space for thinking, for practice. To make permeable the barriers between the arts and sciences, for example, that each lay claim to narrative strategy and form. I think she is trying to resurrect narrative in sociology and reveal its essential place. I found her argument quite sophisticated.

Additionally, Richardson is practicing her feminist principles, often diverting and shocking, but they are invariably related to her particular critique of the academy. She also is actively mentoring others in her book. She speaks, almost conspiratorially, about how to get published and about feminist publishing houses.

Riehl: Speaking of her writing practice specifically, I found one of the best parts of the book to be the poem about Louisa May and her reflections on it. In studies of education, we try to find ways to represent what teachers and students experience in schools, or what they tell us they experience. Using a poetic form to do that would be so unusual, it would raise serious questions about the accuracy of the representation. And yet, I was deeply struck by the verisimilitude of Richardson's poem. I was convinced by her analytical argument that a poem could actually be a more faithful rendition of a story told to an interviewer than a straight transcription, and I felt that her poem did indeed render Louisa May's story truthfully and in the proper spirit. Poetry, the poetic form, is an innovative way to acknowledge the co-creation that goes on between a researcher and the researched.

Hassinger: She takes an interesting moral stance on method. She talks about narrative as a site of moral responsibility, referring particularly to those narratives she calls the "collective stories" of those that have been marginalized, devalued, erased.

In feminist therapy our project includes an effort to illuminate the cultural stories that are both embedded in and contain women's stories, problems, and opportunities. These stories provide context and support for a critical analysis of one's circumstances. They have the power to heal, offer sources of solidarity, and reconnect us to an authentic voice and to one another. Richardson believes that sociology has the responsibility to uncover and tell these stories and to contribute to healing. She pushes the boundaries of the discipline in this way, very much part of the feminist practitioner's agenda. For example, we know from trauma theory and work with severely traumatized people, that healing requires the recovering of the capacity to turn experience into narrative, a story about one's personal 
history that reflects an integration of thought and feeling in memory. I'm wondering about how the recent emphasis of narrative strategies in so many disciplines may reflect a sort of collective effort at healing, an effort to evolve a more integrated theory and practice against strong forces of resistance. The resistance appears in all sorts of places, including the academy. Feminists describe these forces that maintain the fracturing and fragmentation of our stories, our thinking, and our work.

Riehl: Jane, do you think Richardson was engaging in a form of "dangerous healing," by using narrative to produce a more authentic academic self, but also by trying to repair a discipline that might strenuously resist it? How did you feel about that?

Hassinger: Well, I feared for her. But I also realize the relative security of her position in her field and her department. She enjoys certain freedoms that come with economic security, tenure, and grown children.

Dutton: Whether she has it right or wrong, complete or incomplete, I was really drawn to her talk about life after tenure.

Her book provides thoughts about how to reinvent yourself. To me her story calls attention to the degrees of freedom that we have as academics. In her own case, she has stayed attached to certain people over time and united with them to create safe spaces both in the discipline and locally at Ohio State. Her professional life and her personal life are being enacted much more fluidly than I imagined was possible.

I was thankful given the stage where she is in her career that she was talking about constructing a life. It was clear that her career wasn't done. It was still very much being created. I find that to be a really hopeful story. However, I was disappointed that she didn't have more practical suggestions and this may have been what you were referring to earlier. I felt like I didn't get enough practical, almost hands-on, nuts and bolts kinds of suggestions about what to do to create safe spaces. I wanted more. I wanted to hear more about her struggles. Sometimes I felt like it came too easily, despite the difficulty, despite the terror, despite the hardship.

Lempert: I would argue that this is her intellectual history contextualized and the early part of her history was developing narrative in sociology. But I think that once she and others introduced narrative to sociology, it got picked up by others, me for one, who became interested in it methodologically and representationally. While we were discovering the power of narrative in the early stages, she had already moved out and on. She's moved into other forms of representation, both of her own life and of ethnography. 
Since reading this, I have been playing with how to represent my grandparent study in poetic form. I have thought about it more pragmatically in terms of affecting policy makers. One of the things she says in the text is that a problem with qualitative research is that it must be read. Quantitative research can often be summarized in charts and graphs with short narrative explanations. Policy makers look at them and go, "Oh yeah, let's write a plan." I hand them a book. They don't want to read my book. So I'm trying to figure out how to make qualitative work accessible to policy makers. And that's the piece that I've been thinking about-the legitimacy and validation of alternative forms of qualitative representation.

Riehl: I want to direct this question to Linda because of what you talked about in architecture. It seems to me that things are not going to remain static and we've been in this narrative turn for a couple of decades in some disciplines, relatively recent in others, but what's going to follow?

Groat: I think in architecture that kind of post-structuralist idea has gone so far that it has frequently contributed to the generation of design proposals irrelevant to complexities of building in and for the real world. And in that sense, it's made architecture very marginalized as a player at the table when decisions about environmental issues and built form are being made. The practical effect has been to zoom back to the other end of the pendulum to a very technician-oriented role, often without the architect at the table. I don't believe that is good for either the profession or the built environment.

In other aspects of my work I've been trying to encourage women and minorities to come into architecture, my argument is that neither the technician nor the artist model is sufficiently powerful to attract non-traditional students who often aim to become change agents. The technician is too instrumental, and the artist is too ambivalent about his/her audience.

Dutton: I understand that Richardson, like the post-structural architect, could really capture people's imaginations. But you do have policy makers who are at the table and they have to make decisions about how to redesign contexts. So how do you meet these pragmatic needs? Is it really pragmatic to write this way? How do you execute this kind of scholarship at the same time that you add value to society?

Riehl: That's an issue in my field too. In education, there are scholars who write about race, class, and gender, who produce representations of experience that lead to a more critical understanding of what happens to people in school. But this literature isn't always read by policy makers and prac- 
titioners; it does not carry the kind of rhetorical power that will capture the attention of decision makers.

Lempert: That's the piece-the rhetorical power for decision makers. You can convey the capsulized experience as she does with Louisa May, but it doesn't give the policy makers the rhetoric to move forward.

Groat: I actually think that argues for encouraging a fluidity of approaches to our disciplines. In this sense, I can agree with Lora that if you don't push the pendulum that far, you might not create sufficient space in the middle. Many disciplines haven't allowed for much fluidity-for conceiving of and representing the work of the field in a variety of ways, depending on the context. We shouldn't be bound by the traditional paradigms of a field, that you can only write in a certain way. But at the same time, you may still need to maintain the traditional paradigm in some contexts.

Dutton: It reminds me of Aida Hurtado's book, The Color of Privilege, when she talked about people who are bicultural. She wrote in a way that valued women who travel so fluidly and fluently across boundaries.

Hassinger: I would say that the challenge, the need for fluidity is both for being effectively strategic and to guard against the tendency to shut out particular marginalized strategies and voices. When those walls are erected, you can be sure that certain stories are excluded and lose power altogether.

Lempert: While on first read Richardson appears to lack race consciousness - as it is conventionally constructed-in fact, she really opens up the experiences of Jewish women as embedded in racism/ethnicism. It's an important contribution and I missed it in our earlier discussions.

Hassinger: One more point, I want to contextualize her work and recognize the significance of her group. Work takes a group. Groups can be empowering and even dangerous! Creating safe spaces can in turn create quite dangerous and subversive outcomes. Resistance and anger and creative revoicings follow.

Dutton: But that's why I liked her cover, and at the same time found it deceptive. It did not represent the group.

Riehl: Looking around this table most of us often feel like solitary figures in our home departments, and that's one reason we value the safe space this group has become for us. However, one way to keep the academy safe is to allow for safe spaces where all the intemperate, illegitimate things can go on, so they don't have to be addressed "back home." 